\title{
Disturbance of mangrove forests causes alterations in estuarine phytoplankton community structure in Malaysian Matang mangrove forests
}

\begin{abstract}
To assess the effects of environmental changes on phytoplankton community structure in a mangrove ecosystem, phytoplankton distribution in Matang mangrove, Malaysia was examined. Phytoplankton and water samples, and in situ environmental parameters from three estuaries with differing levels of disturbance were examined monthly for one year. Two species, Cyclotella choctawhatcheeana and Skeletonema costatum, were dominant in the least disturbed and moderately disturbed areas, respectively. Skeletonema costatum was also the most dominant in the most disturbed area. Significant differences in phytoplankton density and biodiversity between the least and most disturbed areas were also observed. Principle component 1 (salinity, conductivity, total solids/water transparency and nitrogenous compounds) and PC2 (dissolved oxygen, $\mathrm{pH}$ and temperature) explained $60.4 \%$ of the total variance. This study illustrated that changes in phytoplankton community structure in Matang mangrove estuaries were significantly correlated with environmental parameters which were in turn influenced by ecosystem disturbance levels as well as seasonal changes.
\end{abstract}

Keyword: Phytoplankton; Diatoms; Biodiversity; Mangrove estuaries; Environmental disturbance 